\title{
PENGARUH FAKTOR-FAKTOR EKONOMI MAKRO TERHADAP RETURN SAHAM DENGAN PROFITABILITAS SEBAGAI VARIABEL INTERVENING PADA PERUSAHAAN PERBANKKAN PERAIH INDONESIA BANKING AWARD (IBA) TAHUN2018
}

\author{
Tuti Zakiyah \\ STIE Putra Bangsa \\ Email: tutizakiyah@gmail.com
}

\begin{abstract}
This study aims to examine and analyze the direct effect of macroeconomic variables on stock returns, as well as the indirect influence of macroeconomic variables on stock returns through profitability as measured by ROA as an intervening variable. This research was conducted on banks that received the IBA 2018 award and were listed on the IDX for the period 2009-2017. The data used is quantitative secondary data obtained by documenting various official sites. In econometrics the research data is included in the panel data. The population in this study were 15 banks and obtained a sample of 10 banks for 9 years using a purposive sampling method to form a panel of 90 samples. Hypothesis testing in this study uses $t$-statistic test to determine the direct effect of independent variables and intervening variables on the dependent variable, and compare the value of direct influence and indirect influence to determine the indirect effect of independent variables on the dependent variable through intervening variables. The results of this study are that inflation does not have a direct influence on stock returns. The BI rate does not have a direct influence on stock returns. and changes in the money supply do not directly affect stock returns. Profitability has a significant positive direct effect on stock returns. Inflation has an indirect influence on stock returns through profitability as an intervening variable. The BI rate has an indirect influence on stock returns through profitability as an intervening variable. and the money supply has an indirect influence on stock returns through profitability as an intervening variable.
\end{abstract}

Keywords: Inflasi, BI rate, Profitabilitas, dan Return Saham 
PENDAHULUAN

Pada tahun 2014 terjadi gejolak perekonomian global yang tidak stabil. Ketidakstabilan ekonomi global menyebabkan adanya perlambatan pertumbuhan ekonomi di berbagai negara termasuk Indonesia. Adanya ketidakstabilan ekonomi global disebabkan karena adanya penghentian program quantitative easing (QE) atau pembelian asset obligasi untuk meningkatkan likuiditas kepasar oleh Bank Sentral AS (The Fed).

Penyebab yang lain adalah adanya perubahan kebijakan moneter Amerika Serikat (AS) dengan menurunkan suku bunga menjadi 0,25\%. Pada tahun 2016 ekonomi Indonesia mulai membaik dan mengalami kenaikan. Perbaikan ini dimulai dari naiknya suku bunga AS menjadi 0,50\% dan pemerintah Indonesia mengubah kebijakan dari BI Rate ke BI 7-Day (Beritasatu.com, 2017). Tujuannya adalah untuk mempersingkat lembaga perbankan yang perlu menunggu setahun untuk menarik uangnya dan suku bunga yang ditetapkan lebih murah. Terdapat beberapa kebijakan lain yang diterapkan oleh Bank Indonesia selain perubahan BI rate menjadi BI 7-Day dan penurunan suku bunga acuan yang diterapkan oleh Bank Indonesia seperti Kelonggaran Loan to Value (LTV) dan Financing to Value (FTV), Penurunan
Giro Wajib Minimum (GWM), Diperkenalkannya Desain Terbaru Uang NKRI, Peresmian Fintech Office (Cermati.com, 2017).

\section{Tabel. I Pertumbuhan ekonomi}

Sumber : bps.go.id, 2018

Penurunan pertumbuhan ekonomi tahun 2014-2015 juga memberikan dampak

\begin{tabular}{cc}
\hline Tahun & Pertumbuhan Ekonomi (\%) \\
\hline 2014 & 5,01 \\
2015 & 4,88 \\
2016 & 5,03 \\
2017 & 5,07 \\
2018 (TW II) & 5,27 \\
\hline
\end{tabular}

negatif pada sektor perbankan. Sektor perbankan mengalami penurunan profitabilitas yang diperoleh pada tahun berikutnya yaitu tahun 2016. Gejolak ekonomi mengakibatkan lesunya penyaluran kredit oleh perbankan karena persoalan supply dan demand yang tidak seimbang. Permintaan kredit dari dunia usaha relatif rendah karena daya beli masyarakat terhadap berbagai komoditas menurun dan penghentian ekspansi ekspor yang dilakukan para pengusaha, sehingga mengurungkan niat pengusaha untuk mengajukan kredit untuk meningkatkan investasi. Pihak perbankan juga melakukan pengereman penawaran kredit karena banyaknya kredit bermasalah atau Non Performing Loan (NPL) dengan nilai NPL per Agustus 2016 berada dilevel 2,32\%. 
Ketua Indonesia Banking School (IBS) Subardjo Joyosumarto menyatakan bahwa transformasi regulasi keuangan yang dilakukan pasca krisis ekonomi 1998 telah membuahkan hasil. Perbankan Indonesia saat ini semakin baik dan berada di zona hijau.Pernyataan ini juga didukung oleh data rasio profitabilitas perbankan yang telah publikasikan oleh OJK, dimana beberapa kelompok perbankan mengalami kenaikan profitabilitas di tahun 2018 (Tempo.co, 2018).

Tabel.2

\section{Kinerja Perbankan Indonesia}

\begin{tabular}{ccc}
\hline Tahun & $\begin{array}{c}\text { Bank Umum } \\
\text { Konvensioal }\end{array}$ & $\begin{array}{c}\text { Bank Umum } \\
\text { Syariah }\end{array}$ \\
\hline 2015 & 2,32 & 0,47 \\
2016 & 2,23 & $(0,61)$ \\
2017 & 2,45 & $(0,26)$ \\
2018 & 2,46 & 0,97 \\
(Juli) & & \\
\hline
\end{tabular}

Sumber : Ojk.go.id, 2018

Adanya hasil yang baik oleh perbankan Indonesia, Tempo Media Group bersama Indonesia Banking School (IBS) menyelenggarakan Indonesia Banking Award (IBA) sebagai bentuk penghargaan bagi bank-bank terbaik di Indonesia. Tahun 2018 adalah tahun ke-11 diselenggarakannya Indonesia Banking Award (IBA). Perserta IBA 2018 terdiri dari bank konvensional, bank umum syariah, dan bank pembangunan daerah (BPD). Penghargaaan IBA 2018 terdiri dari delapan kategori penghargaan yang ditentukan. Delapan kategori tersebut adalah The Most efficient Bank, The Most Reliable Bank, The Best Bank in digital Service, The Best Bank in Retail banking Service, The Best Productivity Bank, Diversity Of The Board, The Best Sharia Business Unit, dan The Best Parenting Bank. Beberapa kategori penghargaan menggunakan kinerja keuangan sebagai tolak ukur penilaian.

Salah satu penilaian kinerja keuangan yang mempengaruhi return saham adalah profitabilitas perusahaan. Profitabilitas adalah kemampuan perusahaan untuk menciptakan laba. Nilai profitabilitas perusahan yang tinggi akan menjadi daya tarik bagi investor untuk menginvestasikan dananya di perusahaan tersebut. Semakin tinggi nilai investasi maka semakin tinggi tambahan modal yang diterima oleh perusahaan. Pengoptimalan modal yang dimiliki perusahaan untuk 
mendapatkan laba akan berpengaruh positif pada return saham yang berarti nilai return saham yang akan diterima investor akan semakin tinggi. Keadaan ekonomi makro suatu negara seperti tingkat inflasi dan faktor ekonomi maktro juga dapat mempengaruhi nilai return saham yang akan diterima investor.

Rumusan Masalah dalam Penelitian ini adalah : (1) Apakah inflasi memiliki pengaruh secara langsung terhadap return saham pada perbankan yang mendapat penghargaan IBA 2018 yang tercatat di BEI periode 2009-2017?. (2) Apakah BI rate memiliki pengaruh secara langsung terhadap return saham pada perbankan yang mendapat penghargaan IBA 2018 yang tercatat di BEI periode 2009-2017?. (3) Apakah Perubahan jumlah uang beredar memiliki pengaruh secara langsung terhadap return saham pada perbankan yang mendapat penghargaan IBA 2018 yang tercatat di BEI periode 2009-2017?. (4) Apakah inflasi memiliki pengaruh secara tidak langsung terhadap return saham melalui profitabilitas sebagai variabel intervening pada perbankan yang mendapat penghargaan IBA 2018 yang tercatat di BEI periode 2009-2017?. (5) Apakah BI rate memiliki pengaruh secara tidak langsung terhadap return saham melalui profitabilitas sebagai variabel intervening pada perbankan yang mendapat penghargaan IBA 2018 yang tercatat di BEI periode 2009-2017?. (6) Apakah Perubahan Jumlah uang beredarmemiliki pengaruh secara tidak langsung terhadap return saham melalui profitabilitas sebagai variabel intervening pada perbankan yang mendapat penghargaan IBA 2018 yang tercatat di BEI periode (7) Apakah profitabilitas memiliki pengaruh secara langsung terhadap return saham pada perbankan yang mendapat penghargaan IBA 2018 yang tercatat di BEI periode 2009-2017?.

\section{KAJIAN PUSTAKA}

\section{Return Saham}

Macam-macam Return Saham Menurut Jogiyanto (2014) ${ }^{1}$, return saham dibedakan menjadi dua jenis, yaitu:

1. Return realisasi (realized return) merupakan return yang telah terjadi. Return realisasi dihitung menggunakan data historis. Return realisasi penting karena digunakan sebagai salah satu pengukur kinerja dari perusahaan. Return realisasi atau return histori ini juga berguna sebagai dasar penentuan return ekspektasi (expected return) dan risiko di masa datang. Pengukuran return realisasi dapat dilakukan dengan berbagai cara, yaitu sebagai berikut:

\footnotetext{
${ }^{1}$ Hartono Jogiyanto, Teori Portofolio dan Analisis Investasi, (Yogyakarta: BPFE-Yogyakarta, 2014), hlm. 263.
} 
a. Return total (total return) Return total merupakan return keseluruhan dari suatu investasi dalam suatu periode tertentu. Return total sering disebut dengan return saja. Return total terdiri dari capital gain(loss) dan yield. Capital gain atau capital loss dihitung menggunakan rumus sebagai berikut: Capital Gain atau Capital Loss $=\frac{P_{1-P_{t-1}}}{P_{1-1}}$

Jika harga investasi sekarang $(\mathrm{Pt})$ lebih tinggi dari harga investasi periode lalu (Pt-1) ini berarti terjadi keuntungan modal (capital gain), sebaliknya terjadi kerugian modal (capital loss). Yield merupakan persentase penerimaan kas periodik terhadap harga investasi periode tertentu dari suatu investasi.

b. Return relatif (relative return), Return total dapat bernilai negatif atau positif. Kadangkala, untuk perhitungan tertentu, misalnya rata-rata geometrik yang menggunakan perhitungan pengakaran, dibutuhkan suatu return yang harus bernilai positif. Return relatif dapat digunakan untuk mendapatkan nilai return yang positif dengan cara menambahkan nilai 1 terhadap nilai return total.

c. Return kumulatif (cumulative return), Returntotal mengukur perubahan kemakmuran yaitu perubahan harga dari saham dan perubahan pendapatan dari dividen yang diterima. Perubahan kemakmuran ini menunjukkan tambahan kekayaan dari kekayaan sebelumnya. Return total hanya mengukur perubahan kemakmuran pada waktu tertentu saja, tetapi tidak mengukur total dari kemakmuran yang dimiliki. Untuk mengetahui total kemakmuran dapat menggunakan indeks kemakmuran kumulatif (cumulative wealth index).

d. Return disesuaikan (adjusted return) yaitu Return total, return relatif dan return kumulatif merupakan return normal, yaitu return yang hanya mengukur perubahan nilai uang tetapi tidak mempertimbangkan daya beli dari nilai uang tersebut. Return disesuaikan adalah return nominal yang disesuaikan dengan tingkat inflasi yang ada.

2. Return ekspektasi (expected return)

Return ekspektasi (expected return) adalah return yang diharapkan akan diperoleh oleh investor di masa mendatang. Berbeda dengan return realisasi yang sifatnya sudah terjadi, return ekspektasi sifatnya belum terjadi. Return ekspektasi dapat dihitung berdasarkan nilai ekspektasi masa depan, nilai-nilai return historis atau dengan model return ekspektasi yang ada. 
Profitabilitas

Wiyono dan

Hadri

$(2017)^{2}$ menyatakan bahwa profitabilitas adalah rasio yang digunakan untuk menunjukan hasil akhir dari kebijakan dan keputusan operasi yang telah dilakukan. Sedangkan menurut Hanafi $(2017)^{3}$ profitabilitas adalah rasio yang mengukur kemampuan perusahaan menghasilkan keuntungan (profitabilitas) pada tingkat penjualan, aset, dan modal saham tertentu.

Return On Asset (ROA) untuk mengukur kemampuan perusahaan menghasilkan laba bersih berdasarkan tingkat aset tertentu. ROA juga sering disebut sebagai ROI (Return On Investment). Rasio yang tinggi menunjukan efisiensi dan efektivitas pengelolaan aset, yang berarti semakin baik. Return On Asset (ROA) dapat dihitung dengan rumus berikut:

$$
\text { Return Un Asset }(\text { ROA })=\frac{\text { Laba Bersih }}{\text { Total Aset }}
$$

\section{Inflasi}

Menurut Panennungi dan Novia $(2017)^{4}$ bahwa inflasi merupakan

${ }^{2}$ Gendro Wiyono \& Kusuma Hadri, Manajemen Keuangan Lanjutan; Berbasis Corporate Value Cration, Edisi 1, Cetakan 1, (Yogyakarta: UPP STIM YKPN, 2017), hlm. 339.

${ }^{3}$ Mamduh Hanafi, Manajemen Keuangan, Cetakan 2, Edisi 2, (Yogyakarta: BPFE, 2017), hlm. 42.

4 Maddaremmeng A. Panennungi \& Novia Xu, Perekonomian Indonesia dalam Tujuh Neraca peningkatan harga-harga secara umum dalam jangka waktu tertentu. Sedangkan menurut Hasyim (2017) menyatakan bahwa inflasi adalah gejala ekonomi yang menunjukan naiknya tingkat harga secara umum yang berkesinambungan. Syaratsyarat terjadinya inflsi yaitu karena adanya kenaikan harga-haraga secara umum dan terus-menerus. Jika hanya satu atau dua jenis barang yang terjadi kenaikan harga, maka hal tersebut belum bisa disebut terjadi inflasi. Kenaikan harga yang bersifat sementara, seperti kenaikan harga musiman, menjelang hari raya, bencana, dan sebagainya juga tidak termasuk dalam inflasi.

Hasyim (2017) ${ }^{5}$ menyatakan bahwa laju inflasi adalah perubahan harga umum yang diukur sebagai berikut:

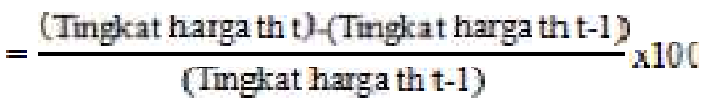

Secara konseptual tingkat harga yang dimaksud adalah tingkat harga ratarata tertimbang dari barang dan jasa dalam perekonomian dan secara umum diukur dengan indeks harga konsumen (consumer price index (CPI) maupun indeks harga produsen (producer price index (PPI)

Makro Ekonomi, Seri 1, (Jakarta: Yayasan Pustaka Obor Indonesia, 2017), hlm. 26.

5 Ali Ibrahim Hasyim, Ekonomi Makro Edisi Pertama Cetakan ke-2 (Depok: KENCANA, 2017), hlm. 186. 


\section{BI Rate}

Menurut Ismail $(2018)^{6}$ bahwa bunga dapat diartikan sebagai harga yang harus dibayar oleh bank dan/atau nasabah sebagai balas jasa atas transaksi antara bank dan nasabah.Dalam perbankan, terdapat dua harga yang selalu ada dalam praktik perbankan yaitu harga beli dan jual. Apabila bank membeli dana dari nasabah, maka bank akan membayar sejumlah harga tertentu kepada nasabah, oleh karena itu dapat dikatakan bahwa bank akan membeli dana dari nasabah dengan harga beli tertentu yang disebut dengan bunga simpanan. Di sisi lain bank juga akan menjual dana kepada nasabah yang membutuhkan dana dengan harga jual tertentu yang diperjanjikan. Harga tersebut merupakan harga jual bank kepada nasabah atau disebut bunga pinjaman. Perbedaan harga jual dan beli yang diaplikasikan dengan adanya perbedaan bunga kredit dan simpanan disebut dengan spread.

Dikutip dari bi.go.id (2018) Sejak 19 Agustus 2016 Bank Indonesia mengganti kebijakan suku bunga BI rate menjadi suku bunga kebijakan BI 7-Day (Reverse) Repo Rate dengan tujuan untuk melakukan penguatan kerangka operasi moneter. Penguatan kerangka operasi moneter ini merupakan hal yang lazim dilakukan di

\footnotetext{
${ }^{6}$ Ismail, Manajemen Perbankan; Dari Teori Menuju Aplikasi, Edisi 1, Cetakan 5, (Jakarta: PRENADA MEDIA GROUP, 2018), hlm. 133.
}

berbagai bank sentral dan merupakan best practice internasional dalam pelaksanaan operasi moneter. Kerangka operasi moneter senantiasa disempurnakan untuk memperkuat efektivitas kebijakan dalam mencapai sasaran inflasi yang ditetapkan. Instrumen BI 7-Day (Reverse) Repo Rate digunakan sebagai suku bunga kebijakan baru karena dapat secara cepat memengaruhi pasar uang, perbankan dan sektor riil. Instrumen BI 7-Day Repo Rate sebagai acuan yang baru memiliki hubungan yang lebih kuat ke suku bunga pasar, sifatnya transaksional atau diperdagangkan di pasar, dan mendorong pendalaman pasar keuangan, khususnya penggunaan instrumen repo.

\section{Jumlah Uang Beredar}

Definisi yang berbeda tentang jumlah uang beredar mencakup juga berbagai jenis deposito yang berlainan. Jumlah uang beredar merupakan suatu stok, yang dirumuskan secara sempit (M) meliputi uang kartal dan deposito yang dapat digunakan sebagai alat tukar.Sebelum tahun 1980, ketika perbedaan antaragiro dan deposito berjangka masih cukup jelas, uang beredar dalam arti sempit dirumuskan sekedar sebagai jumlah uang kartal dan deposito berjangka. Perkembangan pasar uang membuat makin meluasnya pengertian M1. 
Definisi yang lebih luas lagi mencakup M2 dan M3. Yang disebut M2 adalah M1 ditambah dengan tabungan dan segala jenis deposito berjangka yang lebih pendek, termasuk juga rekening pasar uang dan pinjaman semalam antar bank. Sedangkan M3 adalah M2 ditambah dengan beberapa komponen. Komponen yang terpenting adalah sertifikat deposito sertifikat deposito adaah deposito tabungan, yang dibuktikan dengan surat atau sertifikat ketimbang catatan dalam buku tabungannya.

Perubahan jumah uang beredar ditentukan oleh hasil interaksi antara masyarakat, lembaga keuangan serta bank sentral. Proses bagaimana interaksi ini berjalan akan dijelaskan mulai dari proses sederhana hingga yang lebih kompleks (lebih realistis).

\section{Penelitian Terdahulu}

1. Softameino rio, yang berjudul Pengaruh Variabel Ekonomi Makro terhadap Return saham deangan hasil yaitu:

a. Variabel X1 yaitu suku bunga deposito tidak berpengaruh secara signifikan terhadap return saham

b. Variabel X2 yaitu inflasi tidak berpengaruh secara signifikan terhadap return saham

c. Variabel X3 yaitu nilai tukar berpengaruh signifikan terhadap return saham
2. Kurniasari dkk, yang berjudul Pengaruh Inflasi Dan Suku Bunga Terhadap Return Saham Dengan Profitabilitas Sebagai Variabel Intervening Di Perbankan Yang Terdaftar Di Bursa Efek Indonesia Tahun 2013-2015 dengan hasil yaitu:

a. inflasi memiliki pengaruh secara langsung terhadap return saham.

b. suku bunga memiliki pengaruh secara langsung terhadap return saham.

c. ROA tidak memiliki pengaruh secara langsung terhadap return saham.

d. inflasi memiliki pengaruh secara tidak langsung terhadap return saham melalui ROA.

e. variabel ROA mengintervening antara suku bunga memiliki pengaruh secara langsung terhadap return saham.

3. La Rahmad Hidayat, Djoko Setyadi, Musdalifah Azis dengan judul Pengaruh Inflasi Dan Suku Bunga Dan Nilai Tukar Rupiah Serta Jumlah Uang Beredar Terhadap Return Saham dengan hasil yaitu:

a. Inflasi, suku bunga, nilai tukar rupiah dan jumlah uang beredar secara bersama-sama memiliki pengaruh yang signifikan terhadap return saham 
b. Inflasi berpengaruh negatif signifikan terhadap return saham indeks LQ 45.

c. Suku bunga berpengaruh positif dan signifikan terhadap return saham indeks LQ 45.

d. Nilai tukar rupiah terhadap Dollar Amerika berpengaruh tidak signifikan terhadap return saham indeks LQ 45.

e. Jumlah uang beredar berpengaruh tidak signifikan terhadap return saham indeks LQ 45.

4. Dewi Sartika, Jeni Susyanti, M. Agus Salim, yang berjudul Pengaruh Inflasi, Suku Bunga Dan Nilai Tukar Terhadap Return Saham Industri Tekstil Dan Garmen Di Bursa Efek Indonesia deangan hasil yaitu:

a. Secara simultan variabel inflasi, suku bunga, dan nilai tukar berpengaruh terhadap return saham pada perusahaan industri tekstil yang terdaftar di bursa efek Indonesia.

b. Secara parsial inflasi berpengaruh terhadap return saham.

c. Secara parsial suku bunga berpengaruh terhadap return saham. Secara parsial nilai tukar berpengaruh terhadap return saham.

5. Puguh Roni Prastowo, Rony Malavia, dan Budi Wahono yang berjudul
Analisis Pengaruh Inflasi, Suku Bunga Dan Nilai Tukar Terhadap Profitabilitas Perbankan dengan hasil yaitu:

1. Tingkat inflasi secara parsial tidak berpengaruh signifikan terhadap profitabilitas perbankan periode 2014-2016.

2. Suku bunga secara parsial tidak berpengaruh signifikan terhadap profitabilitas perbankan periode 2014-2016.

3. Nilai Tukar secara parsial tidak berpengruh signifikan terhadap profitabilitas perbankan periode 2014-2016.

\section{Kerangka Teoritis}

berdasarkan landasan teori diatas, kerangka pemikiran dalam penelitian ini adalah:

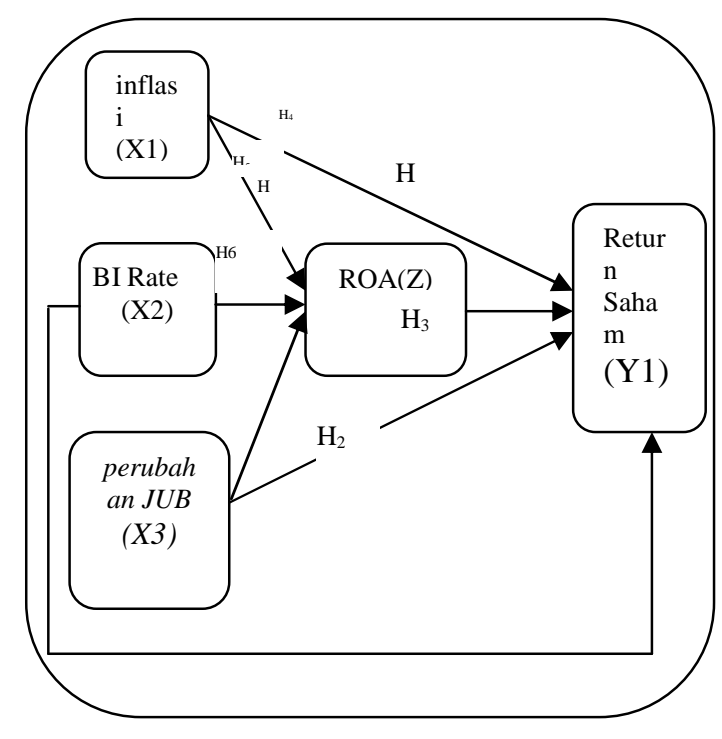

Gambar.1 Model Empiris 


\subsection{Hipotesis}

$\mathrm{H}_{1}$ : berdasarkan kerangka pikir sebelumnya, maka hipotesis dalam penelitian ini adalah sebagai berikut:

Inflasi memiliki pengaruh secara langsung terhadap return saham pada perbankan yang mendapat penghargaan IBA 2018 yang tercatat di BEI periode 2009-2017

$\mathrm{H}_{2}$ : $\quad$ BI rate memiliki pengaruh secara langsung terhadap return saham pada perbankan yang mendapat penghargaan IBA 2018 yang tercatat di BEI periode 2009-2017

$\mathrm{H}_{3}$ : Perubahan Jumlah Uang Beredar memiliki pengaruh secara langsung terhadap return saham pada perbankan yang mendapat penghargaan IBA 2018 yang tercatat di BEI periode 2009-2017

$\mathrm{H}_{4}$ : Inflasi memiliki pengaruh secara langsung terhadap return saham melalui profitabilitas sebagai variabel intervening pada perbankan yang mendapat penghargaan IBA 2018 yang tercatat di BEI periode 2009-2017

$\mathrm{H}_{3}$ : $\mathrm{BI}$ rate memiliki pengaruh secara

langsung terhadap return saham melalui profitabilitas sebagai variabel intervening pada perbankan yang mendapat penghargaan IBA 2018 yang tercatat di BEI periode 2009-2017
$\mathrm{H}_{6}$ : Perubahan Jumlah Uang beredar memiliki pengaruh secara tidak langsung terhadap return saham melalui profitabilitas sebagai variabel intervening pada perbankan yang mendapat penghargaan IBA 2018 yang tercatat di BEI periode 2009-2017

$\mathrm{H}_{7}$ : Profitabilitas memiliki pengaruh secara langsung terhadap return saham pada perbankan yang mendapat penghargaan IBA 2018 yang tercatat di BEI periode 2009-2017.

\section{METODOLOGI PENELITIAN}

\section{Obyek dan Subjek Penelitian}

Obyek penelitian adalah berbagai variabel yang akan diteliti dalam penelitian. Dalam penelitian ini obyek penelitiannya adalah inflasi, BI rate, profitabilitas menggunakan ROA, dan return saham.

Subyek penelitian adalah Perbankan yang mendapatkan penghargaan IBA 2018 digunakan oleh penulis sebagai subyek dalam penelitian ini.

\section{Sampel Penelitian}

Tungga A dkk (2014) ${ }^{7}$ menyatakan bahwa sampel adalah sebagian dari elemenelemen populasi. Metode penarikan sampel dalam penelitian ini menggunakan metode purposive sampling, dimana penarikan

\footnotetext{
${ }^{7}$ A. Tungga, dkk., Metodologi Penelitian Bisnis, (Yogyakarta: Graha Ilmu, 2014), hlm. 79.
} 
sampel berdasarkan kriteria yang telah ditentukan, yaitu:

1. Dalam berbagai rasio profitabilitas, rasio yang digunakan dalam penelitian ini adalah Return On Asset (ROA).

2. Perbankan yang mempublikasikan laporan keuangan secara lengkap berturut-turut di BEI dari tahun 20092017.

Berdasarkan berbagai kriteria yang ditentukan terdapat 10 perusahaan yang dijadikan sampel dengan periode penelitian selama 9 tahun dengan hasil penarikan sampel sebanyak 90 sampel.

\section{Definisi Operasional Variabel}

Untuk lebih memudahkan definisi variabel penelitian ini, maka dapat dilihat seperti pada tabel berikut ini:

\section{Tabel. 3 Definisi Operasional Variabel}

\begin{tabular}{|c|c|c|}
\hline $\begin{array}{l}\text { Vari } \\
\text { abel }\end{array}$ & $\begin{array}{l}\text { Definisi } \\
\text { Operasional }\end{array}$ & Rumus \\
\hline $\begin{array}{l}\text { Ret } \\
\text { urn } \\
\text { sah } \\
\text { am }\end{array}$ & $\begin{array}{l}\text { Return saham } \\
\text { adalah tingkat } \\
\text { keuntungan } \\
\text { yang akan } \\
\text { diperoleh oleh } \\
\text { investor atas } \\
\text { hasil investasi } \\
\text { sahamnya } \\
\text { dalam suatu } \\
\text { perusahaan. } \\
\text { Return saham } \\
\text { dalam dihitung } \\
\text { dengan rumus } \\
\text { (Jogiyanto, } \\
\text { 2014:263): }\end{array}$ & Copital Goin ala Copita Lass $=\frac{{ }_{r} \gamma_{\mathrm{t}}}{\mathrm{P}_{\mathrm{H}}}$ \\
\hline
\end{tabular}

\begin{tabular}{|c|c|c|}
\hline $\begin{array}{l}\text { (RO } \\
\mathrm{A})\end{array}$ & $\begin{array}{l}\text { kemampuan } \\
\text { perusahaan } \\
\text { dalam } \\
\text { menghasilkan } \\
\text { keuntungan dari } \\
\text { Asset }\end{array}$ & $($ ROA $)=\frac{\text { Laba Dersur }}{\text { Total Asat }}$ \\
\hline $\begin{array}{l}\text { Infl } \\
\text { asi }\end{array}$ & $\begin{array}{l}\text { kenaikan harga } \\
\text { secara umum } \\
\text { secara terus } \\
\text {-menerus. Laju } \\
\text { inflasi dapat } \\
\text { dihitung dengan } \\
\text { rumus berikut } \\
\text { (hasyim,2017) }\end{array}$ & $\frac{\text { (Trakt harga t)-[ingt ga trt-l) }}{\text { (Tingkat herga talunt-l) }}$ \\
\hline $\begin{array}{l}\text { BI } \\
\text { Rat }\end{array}$ & $\begin{array}{l}\text { suku bunga } \\
\text { acuan pasar } \\
\text { uang yang } \\
\text { mempengaruhi } \\
\text { suku pinjaman } \\
\text { maupun suku } \\
\text { bunga } \\
\text { simpanan. }\end{array}$ & $\begin{array}{l}\text { Rata-rata tahunan dari data } \\
\text { BI rate bulanan yang } \\
\text { diterbitan oleh Bank } \\
\text { Indonesia dan Bappenas }\end{array}$ \\
\hline $\begin{array}{l}\text { Per } \\
\text { JU } \\
\text { B }\end{array}$ & $\begin{array}{l}\text { dalam arti luas } \\
\text { M2 } \\
\text { +M1ditambah } \\
\text { dengan uang } \\
\text { kuasi, yang di } \\
\text { Indonesia } \\
\text { deposito } \\
\text { berjangka }\end{array}$ & $\frac{(U B \text { tahun } t)-(U B B \text { tahnt-l) }}{(\pi B \text { tahnt }-1)}$ \\
\hline
\end{tabular}

\section{Teknik Analisis Data}

\section{Statistik Deskriptif}

Statistik deskriptif dapat dijelaskan oleh jumlah sampel, nilai minimum, nilai maxsimum, nilai rata-rata dan standar deviasi tiap variabel yang digunakan. 
Dimana analisis ini merupakan suatu hal yang mendasar untuk menggambarkan keadaan data secara umum.

\section{Analisis Jalur (Path Analysis)}

Metode analisis jalur (Path Analysis) digunakan untuk menguji pengaruh variabel intervening. Analisis jalur merupakan perluasan dari analisis regresi linear berganda, atau analisis jalur adalah penggunaan analisis regresi untuk menaksir hubungan kausalitas antar variabel yang telah ditetapkan sebelumnya berdasarkan teori. Untuk mengetahui pengaruh mediasi ini diuji menggunakan sobel test (Ghozali, $2011)^{8}$.

Struktur hubungan variabel tersebut dapat dinyataan kedalam persamaan regresi, yaitu :

Struktur I : $\mathrm{Y}_{1}=\mathrm{PY}_{1} \mathrm{X}_{1}+\mathrm{PY}_{1} \mathrm{X}_{2}+\mathrm{PY}_{1} \mathrm{X}_{3}+$ e

Struktur II : $\mathrm{Y}_{2}=\mathrm{PY}_{2} \mathrm{X}_{1}+\mathrm{PY}_{2} \mathrm{X}_{2}+\mathrm{PY}_{2} \mathrm{X}_{3}$

$$
+\mathrm{PY}_{2} \mathrm{Y}_{1}+\mathrm{e}
$$

\footnotetext{
${ }^{8}$ Imam Ghozali, Aplikasi Analisis Multivariate Dan Ekonometrika E-Views 10, Cetakan 2, Edisi 2, (Semarang: Badan Penerbit UNDIP).
} 
HASIL DAN PEMBAHASAN

\section{Statistik Deskriptif}

Tabel.4 Descriptive Statistics

\begin{tabular}{|l|r|r|r|}
\hline & Mean & Std. Deviation & N \\
\hline ROA & 1.8018 & 1.02950 & 90 \\
Inflasi & 5.2000 & 1.14697 & 90 \\
BI Rate & 6.4089 & .92527 & 90 \\
P JUB & .2136 & .25101 & 90 \\
\hline
\end{tabular}

\section{Analisi Struktural I}

\section{A. Menggambarkan Analisis Jalur Sub}

\section{Struktural I}

Hasil analisis Regresi linier berganda menggunakan SPSS adalah sebagai berikut:

Tabel. 5 Coefficients ${ }^{\mathrm{a}}$

\begin{tabular}{|c|c|c|c|c|c|}
\hline \multirow[b]{2}{*}{ Model } & \multicolumn{2}{|c|}{$\begin{array}{c}\text { Unstandardized } \\
\text { Coefficients }\end{array}$} & \multirow{2}{*}{$\begin{array}{c}\begin{array}{c}\text { Standardi } \\
\text { zed } \\
\text { Coefficie } \\
\text { nts }\end{array} \\
\text { Beta }\end{array}$} & \multirow[b]{2}{*}{$\mathrm{T}$} & \multirow[b]{2}{*}{ Sig. } \\
\hline & B & $\begin{array}{l}\text { Std. } \\
\text { Error }\end{array}$ & & & \\
\hline $\begin{array}{l}1 \text { (Const } \\
\text { ant) }\end{array}$ & 2.491 & 1.235 & & 2.017 & .047 \\
\hline Inflasi & .295 & .150 & .329 & 1.971 & .052 \\
\hline $\begin{array}{l}\mathrm{BI} \\
\text { Rate }\end{array}$ & -.333 & .240 & -.299 & -1.386 & .169 \\
\hline $\begin{array}{l}P \\
J U B\end{array}$ & -.417 & .641 & -.102 & -.651 & .517 \\
\hline
\end{tabular}

Dari hasil diatas dapat diperoleh model sub struktural I ini dapat digambarkan analisis jalur sebagai berikut:

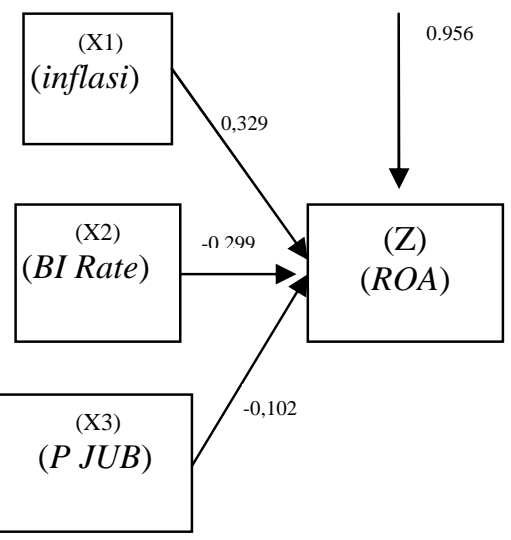

\section{Gambar 2. Sub Struktural I}

Pada gambar di atas maka dapat menunjukan persamaan regresi dari penelitian sub struktural I adalah sebagai berikut:

$\mathrm{Y}_{1}=0.329 \mathrm{X}_{1}-0.299 \mathrm{X}_{2}-0.102 \mathrm{X}_{3}+$ 0.956

1. Koefisien jalur untuk Inflasi (X1) sebesar 0.329. Hal ini berarti jika variabel Inflasi mengalami penurunan sebesar $1 \%$, maka akan meningkatkan ROA sebesar 0.329, dengan asumsi variabel bebas yang lain tetap (X1, $\mathrm{X} 2$ dan $\mathrm{X} 3=0$ ).

2. Koefisien jalur untuk BI Rate (X2) sebesar -0.299. Hal ini berarti jika 
variabel BI Rate mengalami kenaikan sebesar $1 \%$, maka akan meningkatkan ROA sebesar -0.299 , dengan asumsi variabel bebas yang lain tetap (X1, $\mathrm{X} 2$ dan $\mathrm{X} 3=0$ )

3. Koefisien jalur untuk Perubahan JUB (X3) sebesar -0.102. Hal ini berarti jika variabel BI Ratemengalami kenaikan sebesar 1\%, maka akan meningkatkan ROA sebesar -0.102, dengan asumsi variabel bebas yang lain tetap $(\mathrm{X} 1, \mathrm{X} 2$ dan $\mathrm{X} 3=0)$

\section{B. Koefisien Determinan I}

Koefisien determinan dilakukan untuk mengetahui besarnya nilai eror pada pengujian yang dapat dilihat sebagi berikut:

Tabel. 6 Model Summary ${ }^{b}$

\begin{tabular}{|c|c|c|c|c|c|c|c|}
\hline \multirow[b]{2}{*}{$\begin{array}{l}\text { M } \\
\text { od } \\
\text { el }\end{array}$} & \multirow[b]{2}{*}{$\mathrm{R}$} & \multirow[b]{2}{*}{$\begin{array}{l}\text { R } \\
\text { Squar } \\
\text { e }\end{array}$} & \multirow[b]{2}{*}{$\begin{array}{c}\text { Adjuste } \\
\text { d R } \\
\text { Square }\end{array}$} & \multirow{2}{*}{$\begin{array}{l}\text { Std. } \\
\text { Error of } \\
\text { the } \\
\text { Estimat } \\
\text { e }\end{array}$} & \multicolumn{3}{|c|}{ Change Statistics } \\
\hline & & & & & $\begin{array}{c}\text { RSquar } \\
\text { e } \\
\text { Change }\end{array}$ & $\begin{array}{l}\text { F } \\
\text { Chan } \\
\text { ge }\end{array}$ & df1 \\
\hline 1 & $\begin{array}{r}.21 \\
0^{\mathrm{a}}\end{array}$ & .044 & .011 & $\begin{array}{r}1.023 \\
98\end{array}$ & .044 & $\begin{array}{r}1.32 \\
1\end{array}$ & 3 \\
\hline
\end{tabular}

Besarnya nilai $\mathrm{R}$ square pada tabel diatas sebesar 0.044. artinya variabel Inflasi, BI rate, dan Perubahan ROA dapat menjelaskan variabel Return Saham sebesar $4.4 \%$. pada pengujian ini digunakan perhitungan 1-R square adalah sebesar 0.856 atau $85.6 \%$ dipengaruhi Faktor lain.

\section{Pengujian Hipotesis}

Tabel. 7 Coefficients Uji Hipotesis ${ }^{\mathrm{a}}$

\begin{tabular}{|c|c|c|c|c|c|}
\hline \multirow[b]{2}{*}{ Model } & \multicolumn{2}{|c|}{$\begin{array}{l}\text { Unstandardized } \\
\text { Coefficients }\end{array}$} & \multirow{2}{*}{$\begin{array}{c}\begin{array}{c}\text { Standardize } \\
\text { d } \\
\text { Coefficients }\end{array} \\
\text { Beta }\end{array}$} & \multirow[b]{2}{*}{$\mathrm{t}$} & \multirow[b]{2}{*}{ Sig. } \\
\hline & B & $\begin{array}{l}\text { Std. } \\
\text { Error }\end{array}$ & & & \\
\hline 1 (Constant) & 2.491 & 1.235 & & & .047 \\
\hline Inflasi & .295 & .150 & .329 & $\begin{array}{r}1.97 \\
1\end{array}$ & .052 \\
\hline BI Rate & -.333 & .240 & -.299 & $\begin{array}{r}1.38 \\
6\end{array}$ & .169 \\
\hline P JUB & -.417 & .641 & -.102 & -.651 & .517 \\
\hline
\end{tabular}

Tabel diatas menunjukan bahwa:

1. Nilai signifikan Inflasi adalah 1.971>0.05. maka dapat disimpulkan terdapat pengaruh yang tidak signifikan Inflasi terhadap ROA. Hal ini menunjukan bahwa kemampuan variabel Inflasi mempengaruhi ROA sebesar 0.295 atau $0.295 \%$.

2. Nilai signifikan BI rateadalah 0.386.>0.05. maka dapat disimpulkan terdapat pengaruh yang tidak signifikan BI Rate 
terhadap ROA. Hal ini menunjukan bahwa kemampuan variabel BI Rate mempengaruhi ROA sebesar -0.333 atau $-33.3 \%$.

3.Nilai signifikan Perubahan Jumlah Uang Beredar adalah $-0.651>0.05$. maka dapat disimpulkan terdapat pengaruh yang tidak signifikan Perubahan Jumlah Uang Beredar terhadap ROA. Hal ini menunjukan bahwa Perubahan Jumlah Uang Beredarkemampuan mempengaruhi ROA sebesar 0.417 atau $4.17 \%$.

\section{Analisis Jalur Sub Struktural II}

\section{A.Menggambarkan Analisis JalurSub}

\section{Struktural II}

Tabel.8 Coefficients II $^{\mathrm{a}}$

\begin{tabular}{|c|c|c|c|c|c|}
\hline \multirow[b]{2}{*}{ Model } & \multicolumn{2}{|c|}{$\begin{array}{l}\text { Unstandardized } \\
\text { Coefficients }\end{array}$} & \multirow{2}{*}{$\begin{array}{c}\begin{array}{c}\text { Standardized } \\
\text { Coefficients }\end{array} \\
\text { Beta }\end{array}$} & \multirow[b]{2}{*}{$t$} & \multirow[b]{2}{*}{ Sig. } \\
\hline & B & $\begin{array}{l}\text { Std. } \\
\text { Error }\end{array}$ & & & \\
\hline stant) & -1.043 & .629 & & 1.657 & .101 \\
\hline Inflasi & -.281 & .076 & -.591 & $\begin{array}{r}- \\
3.683\end{array}$ & .000 \\
\hline $\begin{array}{l}\mathrm{BI} \\
\text { Rate }\end{array}$ & .384 & . 121 & .652 & 3.172 & .002 \\
\hline P JUB & .741 & .320 & .341 & 2.316 & .023 \\
\hline ROA & .088 & .054 & .167 & 1.647 & .103 \\
\hline
\end{tabular}

\section{Gambar. 3 Jalur Sub Struktural II}

Pada gambar di atas maka dapat menunjukan persamaan regresi dari penelitian sub struktural I adalah sebagai berikut:

$\mathrm{Y}_{2}=-0.591+0.652 \mathrm{X}_{2}+0.341 \mathrm{X}_{3}+$ $0.167 \mathrm{X}_{4}+0.837$

Artinya:

1. Koefisien jalur untuk Inflasi (X1) sebesar -0.591. Hal ini berarti jika variabel Inflasi mengalami penurunan 
sebesar 1\%, maka akan meningkatkan Return saham sebesar -0.591 , dengan asumsi variabel bebas yang lain tetap $(\mathrm{X} 1, \mathrm{X} 2, \mathrm{X} 3$ dan $\mathrm{X} 34=0)$.

4. Koefisien jalur untuk BI Rate (X2) sebesar 0.652. Hal ini berarti jika variabel BI Ratemengalami kenaikan sebesar $1 \%$, maka akan meningkatkan Return saham sebesar 0.652, dengan asumsi variabel bebas yang lain tetap $(\mathrm{X} 1, \mathrm{X} 2, \mathrm{X} 3$ dan $\mathrm{X} 4=0)$

5. Koefisien jalur untuk Perubahan JUB(X3) sebesar 0.341. Hal ini berarti jika variable Perubahan JUB mengalami kenaikan sebesar $1 \%$, maka akan meningkatkan Return saham sebesar 0.341 , dengan asumsi variabel bebas yang lain tetap (X1, X2, X3dan $\mathrm{X} 4=0)$

6. Koefisien jalur untuk ROA (X4) sebesar 0.341. Hal ini berarti jika variabel ROA mengalami kenaikan sebesar $1 \%$, maka akan meningkatkan Return saham sebesar 0.341, dengan asumsi variabel bebas yang lain tetap $(\mathrm{X} 1, \mathrm{X} 2, \mathrm{X} 3$ dan $\mathrm{X} 4=0)$

\section{B. Koefisien Determinan II}

Koefisien determinan persamaan dilakukan untuk mengetahui besarnya nilai eror pada pengujian yang dapat dilihat sebagi berikut:

Tabel. 9 Model Summary ${ }^{b}$

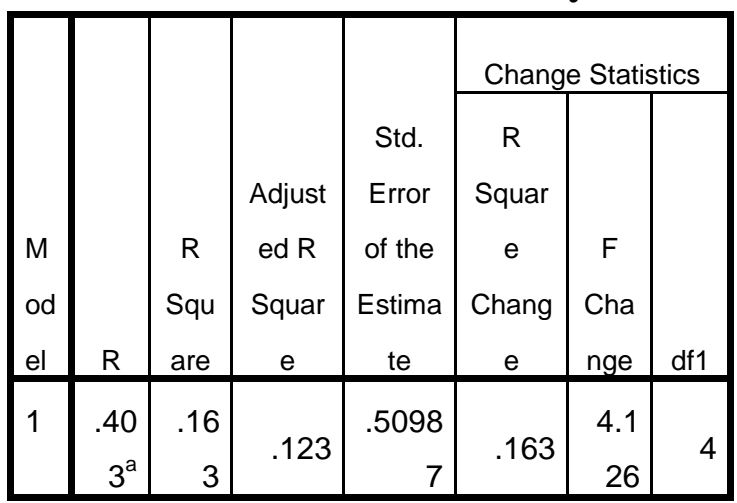

Besarnya nilai $\mathrm{R}$ square pada tabel diatas sebesar 0.123. artinya variabel Inflasi, BI rate, dan Perubahan JUB dan ROA dapat menjelaskan variabel Return Saham sebesar $12.3 \%$. pada pengujian ini digunakan perhitungan 1-R square adalah dipengaruhi Faktor lain. 


\section{Uji Hipotesis}

Tabel. 10 Coefficients uji hipotesis ${ }^{\mathrm{a}}$

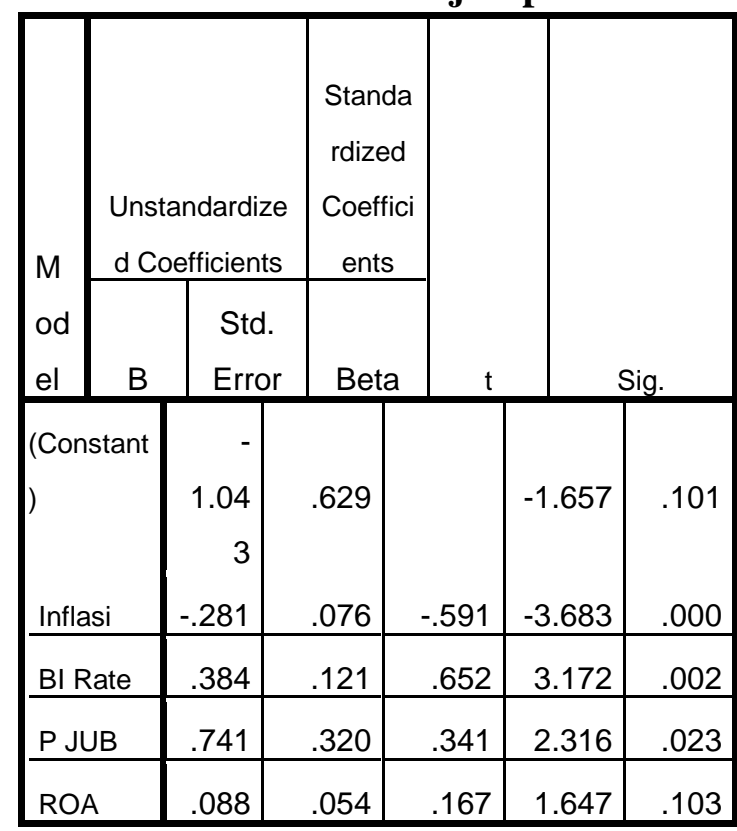

Tabel diatas menunjukan bahwa:

1. Nilai signifikan Inflasi adalah $0.00<0.05$. maka dapat disimpulkan terdapat pengaruh yang signifikan Inflasi terhadap Return saham. Hal ini menunjukan bahwa kemampuan variabel Inflasi mempengaruhi Return saham sebesar 0.281atau $28,1 \%$.

2. Nilai signifikan BI rateadalah -0.02 <0.05. maka dapat disimpulkan terdapat pengaruh yang signifikan $B I$ Rate terhadap Return saham. Hal ini menunjukan bahwa kemampuan variabel BI Rate mempengaruhi Return sahamsebesar 0.384 atau $38.4 \%$.

3. Nilai signifikan Perubahan Jumlah Uang Beredar adalah $0.23<0.05$. maka dapat disimpulkan terdapat pengaruh yang signifikan Perubahan Jumlah Uang Beredar terhadap Return saham. Hal ini menunjukan bahwa Perubahan Jumlah Uang Beredar kemampuan mempengaruhi Return sahamsebesar 0.741 atau $74.1 \%$.

4. Nilai signifikan Perubahan ROAadalah $0.103>0.05$. maka dapat disimpulkan terdapat pengaruh yang tidak signifikan ROAterhadap Return Saham. Hal ini menunjukan bahwa Perubahan ROA kemampuan mempengaruhi Return Sahamsebesar 0.088 atau $8.80 \%$.

\section{Analisis Pengaruh Langsung Dan} Pengaruh Tidak Langsung Serta Pengaruh Total Variabel Eksogen

\section{Terhadap Variabel Endogen}

Berdasarkan pada hasil pembahasan yang menunjukan analisis sub struktural I sampai denga sub struktural II maka dapat digambarkan analisis jalur pada penelitian ini sebagai berikut:

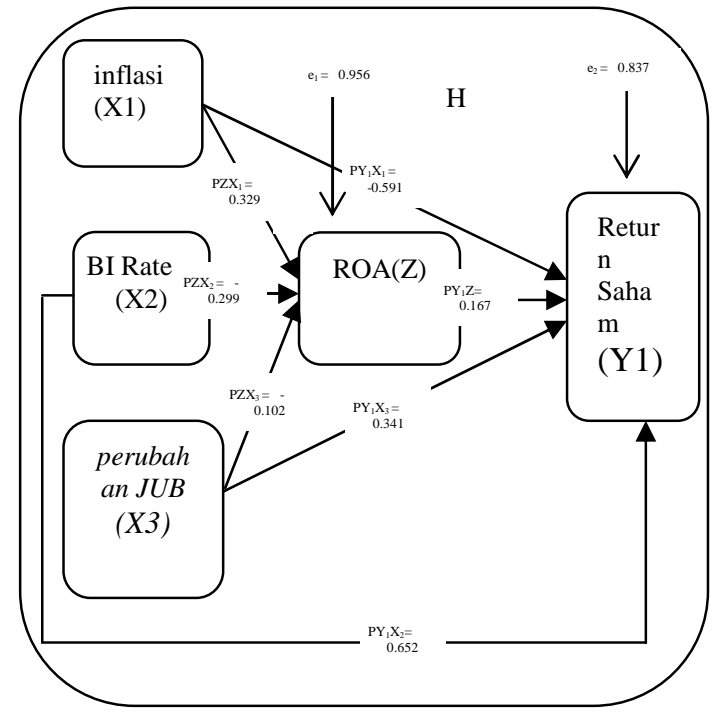




\section{Gambar. 4 Hasil Analisis Jalur}

Berdasarkan hasil pembahasan sebelumnya, maka dapat silakukan perhitungan pengaruh langsung variabel eksogen terhadap variabel endogen sebagai berikut:

1. Pengaruh Inflasi terhadap ROA $\left(\mathrm{PZX}_{1}\right)$ sebesar 0.329

2. Pengaruh BI Rate terhadap ROA $\left(\mathrm{PZX}_{2}\right)$ sebesar -0.299

3. Pengaruh Jumlah Uang Beredarterhadap ROA $\left(\mathrm{PZX}_{3}\right)$ sebesar $-0.102$

4. Pengaruh Inflasi terhadap Return Saham $\left(\mathrm{PY}_{1} \mathrm{X}_{1}\right)$ sebesar -0.591

5. Pengaruh BI Rate terhadap Return Saham $\left(\mathrm{PY}_{1} \mathrm{X}_{2}\right)$ sebesar 0.652

6. Pengaruh Jumlah Uang Beredar terhadap Return Saham $\left(\mathrm{PY}_{1} \mathrm{X}_{3}\right)$ sebesar 0.341

7. Pengaruh Profitabilitas terhadap Return Saham ( $\left.\mathrm{PY}_{1} \mathrm{Z}\right)$ sebesar 0.167

Berdasarkan hasil pembahasan diatas maka dapat dilakukan perhitungan pengaruh tidak langsung variabel eksogen terhadap variabel endogen sebagai berikut:
1. Pengaruh Inflasi terhadap Return Saham melalui ROA $\left(\mathrm{PZX}_{1} \mathrm{X} \quad \mathrm{PY}_{1} \mathrm{Z}\right)$ sebesar $0.329 \times 0.167=0.055$

2. Pengaruh BI Rate terhadap Return Saham melalui ROA $\left(\mathrm{PZX}_{2} \mathrm{X} \quad \mathrm{PY}_{1} \mathrm{Z}\right)$ sebesar $-0.299 \times 0.167=-0.05$

3. Pengaruh Jumlah Uang Beredar terhadap Return Saham melalui ROA $\left(\mathrm{PZX}_{3} \mathrm{X} \mathrm{PY}_{1} \mathrm{Z}\right)$ sebesar $-0.102 \times 0.167$ $=-0.017$

Berdasarkan hasil pembahasan diatas maka dapat dilakukan perhitungan total pengaruh variabel eksogen terhadap variabel endogen sebagai berikut:

1. Pengaruh Inflasi terhadap Return Saham melalui ROA $\left(\mathrm{PZX}_{1}+\mathrm{PY}_{1} \mathrm{Z}\right)$ sebesar $0.329+0.167=0.496$

2. Pengaruh BI Rate terhadap Return Saham melalui ROA $\left(\mathrm{PZX}_{2} \mathrm{X} \mathrm{PY}_{1} \mathrm{Z}\right)$ sebesar $-0.299+0.167=-0.132$

3. Pengaruh Jumlah uang Beredar terhadap Return Saham melalui ROA $\left(\mathrm{PZX}_{3} \times \mathrm{PY}_{1} \mathrm{Z}\right)$ sebesar $-0.102+0.167$ $=0.065$ 


\section{KESIMPULAN}

Berdasarkan penjelasan-penjelasan sebelumnya maka dapat disimpulkan sebagai berikut:

1. Inflasi berpengaruh signifikan secara langsung terhadap Return Saham Pada Perbankan peraih IBA 2018.

2. BI Rate berpengaruh signifikan secara langsung terhadap Return Saham Pada Perbankan peraih IBA 2018.

3. Jumlah Uang Beredar berpengaruh signifikan secara langsung terhadap Return Saham Pada Perbankan peraih IBA 2018.

4. Inflasi berpengaruh secara tidak langsung terhadap Return Saham melalui ROA Pada Perbankan peraih IBA 2018.

5. BI Rate tidak berpengaruh secara tidak langsung terhadap Return Saham melalui ROA Pada Perbankan peraih IBA 2018.

6. Jumlah Uang Beredar tidak berpengaruh secara tidak langsung terhadap Return Saham melalui ROA Pada Perbankan peraih IBA 2018

7. ROA berpengaruh tidak signifikan secara langsung terhadap Return Saham.

\section{Saran}

1. Bagi perusahaan perlu memperhatikan aspek yang berpengaruh langsung terhadap return saham seperti inflasi, $\mathrm{BI}$ rate dan jumlah uang beredaryang dapat mempengaruhi minat investasi para investor.

2. Bagi investor dapat menjadikan inflasi, $\mathrm{BI}$ rate dan jumlah uang beredar sebagai acuan dalam berinvestasi.

3. Bagi peneliti selanjutnya dapat menambahkan variabel lain dari faktor internal maupun eksternal yang dapat mempengaruhi return saham.

\section{Keterbatasan Penelitian}

1. Ada perbankan yang tidak melaporkan laporan tahunan secara lengkap periode 2009-2017, sehingga akun-akun yang dibutuhkan tidak tersedia

2. Jumlah perbankan yang menjadi sampel yang digunakan penelitian terlalu sedikit sehingga membutuhkan waktu periode yang panjang

3. Penelitian ini terbatas pada variabel Inflasi, BI Rate, Jumlah Uang Beredar, ROA, dan Return Saham

\section{DAFTAR PUSTAKA}

Ghozali, Imam. 2017. APLIKASIANALISIS MULTIVARIATE $D A N$ EKONOMETRIKA Eiews 10 Cet.2, 
Ed.2.Semarang: Badan PenerbitUNDIP.

Hanafi, Mamduh M. 2017. MANAJEMEN KEUANGAN Cet 2, Ed 2. Yogyakarta: BPFE-YOGYAKARTA.

Hasyim, Ali Ibarhim. 2017. EKONOMI MAKRO Edisi Pertama Cetakan ke-2. Depok: KENCANA.

Jogiyanto Hartono. 2014. Teori Portofolio dan Analisis Investasi. Yogyakarta: BPFE-Yogyakarta.

Kurniasari, Wulan, Adi Wiratno \& Muhammad Yusuf. 2018. Pengaruh Inflasi Dan Suku Bunga Terhadap Return Saham Dengan Profitabilitas Sebagai Variabel Intervening Di Perbankan Yang Terdaftar Di Bursa Efek Indonesia Tahun 2013-2015. Journal Of Accounting Science, Vol. 2 No. 1 EISSN 2548-3501.

Rio Softameiono, 2017 Pengaruh variabel makro terhadap return saham perbankan pada BEI, http://eprints.umm.ac.id/id/eprint/923 1

Panennungi, Maddaremmeng A \& Novia Xu.2017. Perekonomian Indonesia dalam Tujuh Neraca Makroekonomi, Seri 1.Jakarta: Yayasan Pustaka Obor Indonesia.

Prastowo, Puguh Roni, Rony Malavia \& Budi wahono. 2018. Analisis Pengaruh Inflasi, Suku Bunga Dan Nilai Tukar Terhadap Profitabilitas Perbankan. e-jurnal Riset Manajemen.

Sartika, Dewi, Jeni Susyanti \& M. Agus Salim. 2018. Pengaruh Inflasi, Suku
Hidayat, La Rahmad, Djoko Setyadi \& Musdalifah Azis. 2017. Pengaruh inflasi dan suku bunga dan nilai tukar rupiah serta jumlah uang beredar terhadap return saham. FORUM EKONOMI, Volume 19 (2), 2017.

Ismail. 2018. MANAJEMEN PERBANKAN: Dari Teori Manuju Aplikasi, Ed 1 Cet 5. Jakarta: PRENADA MEDIA GROUP.

Bunga Dan Nilai Tukar Terhadap Return Saham Industri Tekstil Dan Garmen Di Bursa Efek Indonesia. eJurnal Riset manajemen.

Tungga A, Ananta Wikrama, Komang Adi Kurniawan Saputra \& Diota Prameswari Vijaya. 2014. Metodologi Penelitian Bisnis. Yogyakarta: Graha Ilmu.

Wiyono, Gendro \& Hadri Kusuma. 2017. MANAJEMEN KEUANGAN LANJUTAN Berbasis Corporate Value cration Edisi 1, Cetakan 1. Yogyakarta: UPP STIM YKPN. 
